\title{
Missions in Contested Places/Spaces: The SPG, Slavery, and Codrington College, Barbados
}

\author{
Janice McLean-Farrell \\ Dirk Romeyn Assistant Professor of Metro-Urban Ministry, New Brunswick \\ Theological Seminary, New Brunswick, NJ, USA \\ jmclean-farrell@nbts.edu \\ Michael Anderson Clarke \\ Principal, Codrington College, Sargeant Street, Barbados \\ mekael@caribsurf.com
}

\begin{abstract}
Mentioning the Society for the Propagation of the Gospel, a seminary, and slavery in the same breath seems incongruous. Nonetheless, within the account of Codrington College, Barbados, the Anglican Communion's first theological college, we find these three inextricably linked. Using a historical-analytical approach, this paper reveals the troubling missionizing principles which advanced oppressive colonial structures, while failing to fully develop the personhood, agency, and full emancipation of the oppressed. We reassess the ways that particular top-down framings of Christianity and missions were used to enslave/oppress Afro-Barbadians, even under the guise of emancipation. Advocating instead for a framework centering emancipation from below, we outline the ways in which this historical account provides insight for contemporary missional hermeneutics/praxis that seeks to uproot racial and economic inequalities, thus pursuing liberation for all.
\end{abstract}

\section{Keywords}

Barbados - missions - Anglican Communion - Codrington College - Society for the Propagation of the Gospel/sPG - emancipation from below - race - economics 
Mentioning the Society for the Propagation of the Gospel (SPG) and a theological seminary in the same breath as slavery seems somewhat of a gross inaccuracy. Nonetheless, the historical reality offers a different story, as these three are inextricably linked. This troubling account speaks of missionary endeavours, a White slave owner's vision, and the ongoing work of Christianization within the Caribbean generally and Codrington College, Barbados, particularly.

Within this paper, we take a historical-analytical approach to excavating the intricacies located within the contested places/spaces created by this triad. In doing so, we uncover troubling and complex missionizing principles which advanced the systems and structures of colonialism, oppression, and the dictates of the powerful, while pointing to others that are oriented towards preserving and developing the personhood, agency, humanity, and full emancipation of the oppressed and marginalized. We evaluate the impact of this colonial mentality on the people of Barbados, their society, Anglicanism, and Codrington College during slavery, the post emancipation period, and in contemporary times. Interrogating racial and economic disparities and questions of missional hermeneutics and economics, we demonstrate that this is also an account with important resonance for contemporary missional reflection and praxis.

As such, this paper invites us to correctly reassess the ways particular topdown framings of Christianity and missions have been, and continue to be, used to enslave and oppress fellow believers, even under the guise of emancipation. It also provides us with fertile ground to till as we divest ourselves of these particular framings and draw on the resources embodied by the oppressed to envision an emancipation from below, where all captives (both the enslaved and the powerful) are set free and the liberation promised in the scriptures shapes the realities governing the lives of Barbadians and the Caribbean people.

The Slave Trade, Barbados, and the Emergence of Codrington College

The emergence of Codrington College, Barbados, must be understood within the wider history of the transatlantic slave trade. This global trade in human cargo that shipped between 10 million and 12 million Africans from Africa to the Americas and the Caribbean from the 16th to the 19th century was comprised 
of three parts. "First, European ships [sailed] to Africa ... with bartering goods, arms, liquor which they [traded] for slaves. [Then] slaves were transported on the same ships to the [Americas] to meet the [plantations'] continuous labor demands. From the [Americas], these ships would convey the [plantations' products - sugar, rice, cotton, rum, etc.] to the cities and palates of Europe" (McLean-Farrell 2016:27). The slave trade was complex, with far-reaching and lasting consequences for much of Europe, Africa, the Americas, and Asia, some of which included forceable migration and victimization of countless African women, men, and children (Palmer 2007). ${ }^{2}$ At the same time, "the profits gained by Americans and Europeans from the slave trade and slavery made possible the development of economic and political growth in major regions of the Americas and Europe" (Williams 1994:103).

Of particular importance here is the fact that the island of Barbados, often portrayed as something of a tropical paradise and "known today for its social amiability and political civility, was Britain's colonial site of the first 'black slave society' - the most systematically violent, brutal, and racially inhumane society of modernity" (Beckles 2016:Preface). First occupied by the British in 1627, the decision English investors took a decade later to "rebuild their economic enterprises upon the foundation of racial debasement and mass enslavement of imported Africans" quickly transformed the colony into a hugely profitable enterprise, with the demand for slave labor accelerating the pace of the transatlantic slave trade. And by 1636 , a political directive was passed stating that "all Africans brought to the island were to be received as lifelong chattels ... [while] subsequent laws also defined them as 'real estate'" (Beckles 2016:Preface).

This was truly the beginning of a new era both in global economic development and in race relations: "With the black society, England's entrepreneurship forged and refashioned the world economic order. Investors and imperial administrators seized the moment and abandoned traditional labour values and relations. The sugar plantations, stocked with thousands of easily replaceable enslaved Africans, spun super-profits ... Record levels of white-owned wealth and black deaths defined the slave plantation as a 'best practice' in the

1 For helpful online resources, see for example, "The Transatlantic Slave Trade," Encyclopedia Britannica, https://www.britannica.com/topic/transatlantic-slave-trade; "The Transatlantic Slave Trade," National Museums Liverpool: https://www.liverpoolmuseums.org.uk/history-of -slavery/transatlantic-slave-trade.

2 See also "Transatlantic Slave Trade," Slavery and Remembrance: A Guide to Sites, Museums, and Memory http://slaveryandremembrance.org/articles/article/?id=Aooo2. 
new business culture" (Beckles 2016:Preface). ${ }^{3}$ At the same time, the British missionary enterprise was taking shape, and The Society for the Propagation of the Gospel in Foreign Parts, known as the SPG, was founded under royal English charter in 1701 as the official overseas missionary arm of the Church of England. It is within this entangled context, then, that the vision for Codrington College takes shape.

\section{3}

\section{Codrington's Bequest: The Slave Owner's Vision}

The foundation of the contested places/spaces we will examine lies in the vision and bequest of Sir Christopher Codrington III. Codrington, born in 1668 on the island of Barbados, was a third-generation landowner whose wealth was a product of slavery, sugar, and molasses. His grandfather arrived in Barbados around 1643; and his father, Christopher Codrington II, increased the family's fortunes to become "one of the richest planters in the West Indies" (Simmons 1972:51). With wealth came political power, and in 1689 Codrington II became Governor General of the Windward Islands, a position later held by his son, Codrington III (Anselm 1960:503). ${ }^{4}$ Codrington III received his early education in Barbados, later completing his education at Oxford (Simons 1972:51). Simmons argues, "Codrington's career at Oxford is characterized by considerable diversity of interests, academic and otherwise. His success in so many varied endeavours evoked opprobrious lines from his detractors, and eulogies from his admirers. [...] Codrington, though brilliant in many ways, spread himself too thinly; consequently, he has made no permanent place as philosopher, scholar, soldier or man of letters" (Simmons 1972:52).

One place, however, where Codrington made a permanent impact was in his vision to establish an institution of comparable quality to All Souls College, Oxford, in Barbados. Codrington College would render it unnecessary for the children of planters to leave the island to further their studies. ${ }^{5}$ Besides this,

3 For educational resources relating to $17^{\text {th }}$ and 18 th century slavery in the Caribbean, see "Runaway Slaves in Britain: bondage, freedom, and race in the eighteenth century" https:// www.runaways.gla.ac.uk/ And for an online interactive resource detailing a fictionalized account of life on a Caribbean plantation, see "The Saint Lauretia Project," https://runaways .gla.ac.uk/minecraft/.

4 A Governor General is a government official normally associated with the British colonies and/or Commonwealth.

5 The planters were the white plantation owners. For further information on planters, slaves, and plantation slavery in the Caribbean, see "Slave Resistance: A Caribbean Study," available at https://scholar.library.miami.edu/slaves/index.html. 
the College would also produce missionary doctors to go to Africa to convert the 'heathen' there. His will stated:

I bequeath my two plantations in Barbados to the Society for Propagation of the Christian Religion in Foreign parts, ... and my desire is to have the plantations continued Intire [sic] and three hundred negroes at least Kept thereon, and A convenient number of Professors and Scholars Maintained there, all of them to be under the vows of Poverty, Chastity, and Obedience, who shall be obliged to Study and Practice Physick and Chyrurgery as well as divinity, that by the apparent usefulness of the former to all mankind, they may Both endear themselves to the People and have the better opportunity's of doing good To mens Souls whilst they are Taking Care of their Bodys.

SIMMONS 1972:53

Codrington's bequest had three prominent provisions. First, the SPG would own the plantations and be responsible for establishing and maintaining the institution. Glasson notes, "Codrington was a member of the minority of West Indies masters who favored the conversion of enslaved people, and his interest in that cause seems to have been part of the reason he left his estate to the Society" (Glasson 2012:143). The Society, a missionary body, "came into being with a Charter granted by William III on 16 June 1701 within the spirit of English charters to 'conquer, occupy and possess' lands occupied by 'heathens and infidels, in whatsoever part of the world' which went back to 1482 " (O'Connor 2000:7). The European 'right to land' and 'having the divine authority' to exercise governmental, economic and social rule over native peoples without their consent, evident in Henry viI's charter, was also central within Pope Nicholas v (1452) and Pope Alexander vi's (1493) Papal bulls. ${ }^{6}$ These bulls and the Doctrine of Discovery they sanctioned "formed the basis for the colonization of America and much of the non-European world" (Miller et al. 2010:7). These edicts enshrined the belief that these nations had a divine responsibility to also bring Christianity to the 'conquered' and enslaved. This resulted in the emergence of a Christian understanding that slavery was both doctrinally

6 While the Papal Bulls Roman Catholic documents primarily focused on Spain and Portugal, their application was adopted by other European countries including Britain. For more on the Papal Bulls see: Dum Diversas, 1452, English translation: http://unamsanctamcatholicam .blogspot.com/2011/o2/dum-diversas-english-translation.html, accessed on December 5, 2020, and The Doctrine of Discovery, 1493: https:/www.gilderlehrman.org/history-resources/ spotlight-primary-source/doctrine-discovery-1493 for an excerpt of this primary text, accessed on December 5, 2020. 
acceptable and consistent with Christianity. This religious assumption underpinned the SPG's work on the Codrington plantations.

Second, the plantations and the College's continued existence required 300 'negro bodies' be kept in perpetual bondage. Third, the envisioned institution's curriculum would have a dual focus: medical (Physick and Chyrurgery) and spiritual (divinity). While the "connection between medical and spiritual power was not unique to West African religions," it was one that factored prominently in the lives of the slaves (Glasson 2012:164). In the execution of Codrington's will, there was therefore the triadic convergence of mission, education, and slavery, and the creation of this contested place/space. It is important to see that the education and christianisation of the slaves was in no way altruistic: Codrington's establishment required the labour and continued enslavement of 300 black bodies. Further, this initiative was not intended to develop their full human potential, but to make them obedient and hardworking slaves, fully committed to the maintenance of colonial society, training them to believe that there was divine authority behind their enslavement.

\subsection{Colonial Hermeneutics: Missionaries as 'Patrons of Slaves'}

For the SPG General Committee, ${ }^{7}$ Codrington's gift was a "remarkable benefaction." But what was the impact of this 'remarkable' gift? For this we turn to the 1711 annual sermon of William Fleetwood, Bishop of St. Asaph, wherein he "acknowledge[s] Codrington's gift, reflect[s] on what it meant for the Society, and urge[s] masters to aid in Christianizing their slaves" (Glasson 2012:143; see also Titus 2010:250-51). Using a "text on Paul's mission to the Gentiles," Fleetwood stressed every Christian's duty to preach the gospel, and the evangelistic duties towards colonial slaves (Titus 2010:250). Fleetwood used his sermon to clarify some misconceptions slave masters had pertaining to these evangelistic duties: namely baptism and manumission, baptism and the treatment of slaves, and the selling of baptized slaves. For Fleetwood, since baptism did not free the slave, masters were to fulfil their evangelistic duty towards them. Regarding the baptism and treatment of slaves, Fleetwood "urged that Christianity commanded mercy and compassion towards all. To deal harshly with the slaves was to disobey Christ. [Thus] on these grounds, he urged slave masters to be true to their religion by their physical treatment

7 The General Committee oversaw the administrative duties of the SPG. Its members were drawn from the SPG members which included: the Archbishop of Canterbury, senior English and Welsh bishops, principal theological professors at Oxford and Cambridge, eminent and influential laity. See: Daniel O'Connor, ed., Three Centuries of Mission: The United Society for the Propagation of the Gospel 1701-200o (London: Bloomsbury Publishing, 2000): 10. Once the Codrington plantations were received, a Barbados Committee was created. 
of the slaves" (Titus 2010:250). Regarding the prohibition on selling a baptized slave, Fleetwood stated "if they could be sold before they were baptized, the Laws of Christ would not deprive the owners of that property after baptism" (Titus 2010:250).

In critically analysing Fleetwood's sermons, one notes that his position, use of the authority of scripture and hermeneutical lens is that of the colonizer. In this context, the biblical text is read and applied in a manner that supports the priorities of those in power: the SPG, the slave masters, and the slavery/ plantation/colonial enterprises; an important reminder that hermeneutics are not neutral. Fleetwood's hermeneutics had three components: paternalism, orthodoxy, and erasure. Paternalism was the masters' 'right to decide' the fate of the oppressed without their input. After all, the masters were divinely appointed to rule over the slaves, and the slaves to be ruled. Orthodoxy spoke to the right to dictate how historical and contemporary events should be interpreted. Within the colonial society, orthodoxy was determined by the colonizer and Empire. Through this lens, all colonial actions, regardless of their brutality and violence, were deemed 'justifiable' in furthering the Christianisation and colonization of the oppressed. Paternalism and orthodoxy could not stand on their own, however, but required the erasure of the humanity and agency of the oppressed, either through demonization or the stripping away of their personhood, cultural, religious, and spiritual features (McLean-Farrell 2016:18-44).

Ironically, Bishop Fleetwood did not see any contradiction between conversion and slavery, though argued that slave owners who resisted evangelising their slaves were in the wrong. He saw the SPG as "becom[ing] the Patrons of at least Three Hundred Slaves," and in christianizing Codrington's slaves, the Society would be "preaching by Example" and modelling to their fellow slave holders how to marry a profitable plantation with slavery and Christianity (Glasson 2012:143-144). This insidious union had an embedded subtext that informed both SPG's missional goals and the spirituality that Fleetwood advances: the maintenance of the colonial social order and the protection of the wealth generated from the poverty and free labour of Africans within the plantocracy/plantation economies. ${ }^{8}$

\subsection{The Execution of the Vision}

The SPG managed the College from a distance, with ambiguity and lackadaisical attitudes. The medical work did not go far, and the grammar school,

8 The Moravians (Jamaica, Barbados, St. Croix) and the Jesuits throughout Latin America and in Maryland with their college at Georgetown also engaged in these practices. See Glasson 2012:145. 
established in 1745, was (initially) for White children only, preparing planters' sons for entrance into college (Ward 2006:86). The school "imitated the English Public Schools both in administration and in curricula" (Simmons 1972:53). For many years, the curricula focused on providing a general education which included philosophy and divinity. This was expanded to lectures in advanced studies in 1748, "following the appointments of professors of Philosophy and Mathematics and surgery, though [the college] never produced medical doctors nor surgeons." ${ }^{\prime}$ The academic side was taken more seriously after the appointment of Bishop William Hart Coleridge, "the first Bishop of the new See of Barbados and the Leeward Islands" (Simmons 1972:54). In 1830, as the first theological college in the Anglican Communion, "the College began training candidates exclusively for ordination under the Rev. J. H. Pinder [the first principal]" (Simmons 1972:54). Also, the College began to educate poorer boys who were not sons of the gentry, though this development was not without its opposition.

While Codrington College was charting a new course in education within a contested place/space, it was vulnerable from onset and its solvency was contingent upon profits from slavery. Further, Codrington's vision to provide basic education and evangelism to his slaves was likewise challenged by other planters. In the grammar school and later College, there was institutionalized dependency upon British entities for leadership and knowledge. Closely aligned with this was the maintenance of the status quo within Barbadian society and the Anglican Church, a legacy that has remained somewhat intact.

\subsection{Failure of the Vision}

Noel Titus delves into the SPG's failure in operating the plantation and specifically maintaining the 3 oo slaves requested by the will. While this may have resulted from serious overworking and poor living conditions, a more inhumane occurrence was also being practiced: "discarding slaves who could no longer work productively." In 1716, "the manager John Smalridge sought the approval of the Society for the disposal of 'refuse Negroes' from the plantation as had been done during the time of General Codrington." Permission was eventually granted by the Barbados Committee to resurrect this practice (Titus 2010:254).

Another hindrance to maintaining the slaves was the attorneys/managers' noncompliance in building a hospital to care for sick slaves or keeping a register of punishments. While a hospital was eventually built in 1805 , by 1819 ,

9 'A Historical Overview of Codrington College,' available at http://www.codrington.org/site/ index.php/historical-overview, accessed on June 23, 2021. 
the committee "approved the manager's intention to covert the hospital into a chapel, and to construct a new hospital." While a chapel was built, there was no evidence supporting the rebuilding of the hospital. Regarding the registration of punishments, "the amelioration programme of the early 1820 s required each plantation to keep a register of all punishments but no register was kept on the Codrington plantations." The explanation offered by SPG agents "was that there were few crimes on the plantations including larceny." For Titus, this larceny was probably due to insufficient food for the slaves (Titus 2010:255). These issues speak to the Society's ignorance of the harsh realities of daily life on the plantation.

At the heart of the SPG's failure was the ongoing "tension between making profits and making converts," with the inescapable interconnections between "spiritual and temporal power ... where employees wielded both the Bible and whip in the SPG's name" (Glasson 2012:157, 161). While the Society believed in the compatibility of Christianity and profiting from slavery and sought to make the Codrington plantations a shining example of this symbiosis, it did not come to pass. Within Barbadian society, "the sugar plantation system dominated economic life in every sense. It occupied the best lands, the laws supported the slave system, and in general all commercial and other economic activity depended on the rhythm of activity of the plantation" (McLean-Farrell 2016:27). Nothing, including this SPG venture, was allowed to disrupt this way of life. ${ }^{10}$ In fact, economic gain trumped christianization of the slaves, and "by 1726 , sixteen years after the death of Christopher Codrington, not one of the Society's slaves had been baptized" (Glasson 2012:155). Throughout much of the slavery period, Codrington's legacy therefore served the White elites, rather than the Afro-Barbadian slaves for whose benefit the legacy was in part intended. In the absence of rigorous hermeneutical and theological evaluation of the conflict between profiteering from slavery and mission, the Christian presence was greatly influenced by the "plantocracy" (Hunte 2001:91).

A significant point often overlooked within the christianization of the slaves is the slaves themselves. They arrived in Barbados with their cultures, religious beliefs, and practices, which continued to provide them spiritual alternatives to Anglican Christianity (Glasson 2012:162). ${ }^{11}$ This is important for two reasons. First, their indigenous spirituality gave the slaves a sense of autonomy, personhood, self-understanding, and some measure of independence; the very fundamentals the missionary enterprise unconsciously intended to control and

\footnotetext{
10 See Titus 2010:256, where he discusses the pressure exerted on the attorneys and managers to conform to the system that was already in place.

11 See also McLean-Farrell (2016), chapter 1.
} 
possibly eliminate. Second, it uncovers the fallacy embedded within the colonized rendering of Christianity undergirding Fleetwood's sermons, the SPG's missionizing practices, and the colonization enterprise, which required slaves to be sub-human, devoid of any intellectual ability or personhood/identity that would enable them to articulate a self-understanding of their humanity and resist the very systems that demanded their bondage. As such, the christianization of slaves was not meant for their emancipation but to make them complicit in, and committed to, their own oppression.

On the Codrington plantations, the Society saw mission as a multi-focused endeavour. First, as a model for the compatibility between Christianity and slavery; next, the conversion of the slave population; then, for providing medical services and education for the enslaved; and finally, the provision of missionaries to support this work and serve the Anglican Church. In executing this mission, however, the SPG inhabited a contested space/place. Underneath this 'beneficent' and 'ground-breaking' missional work was a framing of Christianity and mission that espoused the supremacy of White Europeans, the orthodoxy of Anglo-Saxon Protestant interpretations of scripture, and the preservation of, and commitment to, the plantation, slavery, and colonial enterprises which required human bondage. Thus, the slaves' significance rested not in their conversion to Christianity, but in the ways in which their Christianization contributed to upholding the plantocracy. It is a sobering reminder to carefully consider our missional and evangelistic motivations at any time.

\section{Mission in the Post Emancipation Period: SPG, Codrington College, and Barbados}

Unlike Jamaica, Barbados stopped importing slaves at an earlier date and depended instead on the population increase of the creole slaves for its labour needs; a population "the planters hoped would passively accept a society of deference which the church would reinforce" (Ward 2006:91). Therefore, even with a Black majority, "its culture was more uniform and more shaped by 'Englishness', to the extent that it was seen as 'Little England'” (Ward 2006:91). While nonconformist religious groups like the Baptists, Moravians, and Methodists thrived in Jamaica, in Barbados, "Anglicanism had an unrivalled authority"; and while other islands were disestablishing the Church of England, "the Barbadian legislature voted to retain establishment" (Ward 2006:91).

In post-independence nation building processes, those in power saw the church as an ally in creating the most useful socio-religious-cultural landscape, supporting and contributing to a God-fearing, highly prosperous, 
stable society. However, even with Black Barbadians in leadership, this 'independence' in many ways mirrored the colonial social stratification on which the country and the Codrington estate had prospered, with everyone in their associated place, as evidenced by this stanza from the hymn All Things Bright and Beautiful:

The rich man in his castle,

The poor man at his gate,

God made then, high, and lowly,

And order'd their estate.

The Book of Common Prayer, HYMN 573

A favourite national hymn, this reveals and symbolically reinforces colonial socio-economic boundaries, with the church's prophetic voice and the scriptural message that so clearly speaks to the redress of social inequalities thunderingly silent. Within the post emancipation era, the legacy of the SPG and Codrington's bequest were visible in three arenas: education, the presence of Black clergy, and the Rio Pongas mission.

\subsection{Education}

In the post emancipation era, SPG and Codrington College continued the Christianisation and 'civilization' of the free Blacks, two essential parts of the colonial enterprise that remained intact, without any consideration for the immediate economic, political, social, or psychological needs of a society traumatised by slavery. This was primarily accomplished through education (Klingberg 1938:476). Administered as the Negro Education Grant (1835-1845), education focused on "providing the newly emancipated slaves and their children with a basic elementary education ... [It] concentrated on two specific areas: vocational and religious education." This again was intended to be practical in the sense of training up a skilled and God-fearing, law-abiding labor force to maintain the status quo (McLean 2014:152). The plantations and the tripartite structure comprising a small White upper class, a small Creole class, and a large lower class survived emancipation (Brock 1982:127-128). Accompanying this tripartite structure was the relationship between race, colour, and class, and its correlation between education and status: "status may be seen as the insidious ranking of others in terms of deference" and in the Caribbean, deference was based on race and the degree within which one came to being White (Brock 1982:128).

Within the colonial framework, 'whiteness' was the standard, and the 'whiter' you were in your speech, actions, and culture, the more 'civilized' and educated 
you were deemed to be, and the higher your social status (McLean-Farrell 2016: 34-35). For creole and Afro-Barbadians, however, 'whiteness' demanded the "colonization of consciousness" and the internalization of the British colonial mindset. ${ }^{12}$ Instead of education inculcating self-esteem and confidence, the goal of this miseducation was to continue to make Afro-Barbadians maintain the colonial status quo and regard themselves as inferior to Europeans, which it did..$^{13}$ Indeed, while certain features of the tripartite structure have changed in Barbados, slave descendants still frequently occupy positions of powerlessness, economic injustice, and cultural impoverishment.

In the Society's annual sermon on May 27, 1836, the Lord Bishop of Gloucester and Bristol stated that "unless means were found to instruct the Negro population, the freedom which was intended to be a blessing might prove to be a curse; a deliverance from the restraints of masters could become a means of licentiousness, unless it be attended with instruction upon the holy restraints of religion" (Klingberg 1938:476). At the heart of this sermon was the fear that unless another system of control replaced slavery, the freed slaves would disrupt society. Education provided that control. Armed with this charge, in 1838 the Society actively engaged in educational provision, focusing on religious instruction and underscoring deference. Through subscriptions and donations, the SPG made progress with its schools for children in Barbados, but these were modelled on English systems with no regard for the pupils' needs or context. By 1851 , there were four primary schools with 6 oo pupils in connection with the College (Klingberg 1938: 476-478). By 1846, Codrington College had graduated 111 students, 67 of whom were from Barbados. ${ }^{14}$

As the provision of education for children became a priority, Codrington College's attention shifted. To broaden the curriculum, in 1875 the College became affiliated with Durham University (England). Under this arrangement, "Codrington College students earned Durham degrees while in residence at Codrington" (Simmons 1972:54). Through the initiative of Principal A. H. Anstey, Codrington expanded its curriculum to include teacher education and other academic disciplines such as rudimentary studies in law and medicine. "The College produced many persons who made their mark in

\footnotetext{
12 The coordinating side of this internalization was an aversion towards 'blackness,' which fostered a self-hate within the colonized people. For a more in-depth discussion see Franz Fanon, Black Skin, White Masks, (New York: Grove Press, 1952 [2008]).

13 For a more in-depth presentation on this maintenance within the education system see: Brock, "The Legacy of Colonialism in West Indian Education" in Keith Watson, ed., Education in the Third World, (London: Croom Helm, 1982).

14 See 'Some Academic Highlights of the College,' http://www.codrington.org/site/index .php/academic-highlights, accessed on June 26, 2021.
} 
teaching, law, medicine, the civil service, as well as in the Church," impacts that continued with Codrington's affiliation with the University of the West Indies in 1965, whereby "students of the College may be admitted to the Licentiate in Theology and the B.A. Theology of the University."15 In the 1970s, Codrington admitted its first female students, Edna Scott and Pearl Kirton, to pursue a part-time course leading to the Diploma in Theology. This course was specifically for lay persons who played a leading role in their church, and those who taught religion in day schools. ${ }^{16}$

The impact of Codrington's bequest and the SPG's educational ventures in shaping Barbados, the Caribbean, and the Anglican Church cannot be denied. Why then, did "Codrington College [not] develop, as would naturally be expected, into a centre of learning for the West Indies?" (Simmons 1972:69). The reasons are multiple, but have one common source: Codrington College was a contested place/space. While it made some dynamic and innovative educational developments, these were all subservient to the role of being an ally in maintaining the status quo. For much of its existence, Codrington was a White space (leadership, professors, students, curriculum). Simmons argues, "the professors, devoted though they were, never looked upon the college as their home, and even though some remained as many as twenty years they eventually "went home" (Simmons 1972:54). The transition from foreign to local leadership eventually happened with the appointment of The Rev Dr Kortright Davis as acting Principal from 1970 to 1971 and The Rev Dr Sehon Goodridge, a Codrington College alumnus, from 1971-1982. ${ }^{17}$

While the College gained academic standing in its affiliation with Durham, it was at the cost of fostering a spirit of free academic inquiry and developing a curriculum responsive to the needs of a changing region preparing for independence and nation building. Codrington's bequest rather contributed to maintaining the status quo. The irony is that Codrington bequeathed his estate for the advancement of the SPG's mandate to be the global missional arm of the Church of England, but Codrington College and the estate stand as symbolic reminders of the fraught relationship between the missionary venture in Barbados, the slave trade, and the Anglican Church as a 'Planters Church'! However, that is not the end of the story.

15 http://www.codrington.org/site/index.php/historical-overview, accessed on June 24, 2021. Note, with the establishment of the University of the West Indies, the college's curriculum has concentrated on theological studies.

16 See 'Some Academic Highlights of the College,' http://www.codrington.org/site/index .php/academic-highlights, accessed on June 26, 2021.

17 "Principals of the College 1830 et seq." http://www.codrington.org/site/index.php/past -principals. 


\subsection{Afro-Barbadian Clergy, the SPG Mission, and the Anglican Church}

In the years following emancipation, Codrington College also begun providing ministerial training for Afro-Barbadians and "encouraging black people to engage in West Indian mission to West Africa" (Ward 2006:91). This vision became the life work of Richard Rawle, Codrington Principal 1847-1864. As part of this venture, "J.H.A. Duport, a young catechist trained at Codrington, went out as a missionary and in 1856 was ordained in Sierra Leone" (Ward 2006:91). Ironically, when another Codrington graduate, John Nathaniel Durant, saw his homeland, Barbados, as the site for his vocation, he was not ordained. He attended Philadelphia Divinity School starting in 186o and was ordained as a deacon in Virginia. However, Durant's return to Barbados "precipitated a crisis ... and a special Act had to be passed by the Barbadian legislature to allow him to officiate as a clergyman in his home country" (Ward 2006:92).

The Special Act permitted Durant to exercise ministry, but he was sent to Tobago, where the presence of White planters was not as prominent. But even there, Durant "was deployed as a curate to an incompetent priest from England" (Ward 2006:92). Once back in Barbados, the only official function to which he was assigned was the burial of the dead (Ward 2006:92). Durant was an outspoken and articulate critic of the status quo, so the SPG perceived him as threat. However, 'conforming' to the status quo did not guarantee equality. This was the case for E. Sanford Thomas, another Codrington student, who, though "less radical than Durant, was nevertheless kept in subordinate positions in the diocese until he was made a rector in 1884" (Ward 2006:92). The SPG's attitudes towards slaves or their descendants in administering Codrington's bequest was ambivalent and paradoxical. The purpose of the bequest was to provide training so that missionary work could flourish in Barbados and in Africa. Yet, the SPG was not equally prepared to enable the beneficiaries of the bequest to flourish and in turn make their missional mark, in fulfilment of the bequest.

As persons educated within a European/colonial framework, the AfroBarbadian clergy also inhabited a contested place/space. While Durant and others "show that there were black Anglicans who had a vision for a church in which English race superiority was displaced, and pride in black identity was affirmed ... their interest was not in rescuing and restoring African values - to have done so would often have been to detract from their claim to be admitted into 'civilised' society" (Ward 2006:98). ${ }^{18}$ For the larger Afro-Barbadian population (domestic workers, peasant farmers, agricultural laborers, "the small urban proletariat and lower-middle-class"), their membership embedded

18 The others that Ward mentions are Robert Gordon of Jamaica, James Theodore Holly from Brooklyn who ministered in Haiti, and George Alexander McGuire from Antigua. 
them within a contested place/space, one whose liturgy provided spiritual sustenance and its membership, prestige, and status, which "was important for educational purposes and provided a cohesive community ethic" (Ward 2006:98). However, their Church's continued alignment with the social structures of "Little England" demanded the indoctrination and internalization of a colonialism/civilization mindset, which denigrated "blackness" and led to a sense of inferiority. This sense of a disvalued self seems to have been etched upon the Afro-Barbadian community's psyche and undergirds the practice of continually looking to the external world for leadership/expertise and devaluing of local contributions and initiatives (Davis 1990:103).

With independence, various changes occurred within the Anglican Church. Notably, dioceses typically had local bishops and the majority of the clergy were Black (Ward 2006:99). The 1970s also saw the rise of the Caribbean Conference of Churches and the Black Power Movement, which focused on nurturing an appreciation of the value of people's experiences in the region and challenging the status quo. But the SPG and the Anglican Church under Barbadian leadership missed an opportunity to contextualise their ministry, ethos, and liturgical practices to engage the winds of change blowing across the island, remaining "too tied to the English values and personnel" (Ward 2006:99). For the Afro-Barbadian church members and clergy, having inherited this prize, there arose the fear of tampering with its structure, form, or expression lest they devalue it. For example, while Anglican churches were replacing the 1861 Hymns Ancient and Modern, updating arcane language and theologically controversial lyrics (as cited previously), the Church in the Caribbean continued to use it until 2010, when a new, little-altered new hymnal was produced.

\subsection{Rio Pongas Mission}

The Rio Pongas mission was a partial fulfilment of Codrington's vision for missionaries to be trained at the College and sent to Africa. In the $184 \mathrm{os}$, the idea emerged that "it would be a glorious opportunity to send educated [Afro-Barbadians] from Barbados back to West Africa to assist in the imperialist work of spreading Western Civilisation and Christianity" (Gibba 2011:54). This is an ancient model where those who had been removed from a society and indoctrinated into new forms of understanding were reintroduced into the old society to carry out indoctrination more thoroughly. ${ }^{19}$ The framework

19 For further discussion of Afro-Caribbean Christians going to West Africa as missionaries, see, for example, Abraham Nana Opare Kwakye, "Returning African Christians in Mission to the Gold Coast," Studies in World Christianity 24:1 (April 2018): 25-45. 
for the mission came from Archdeacon J. M. Tree of Barbados (1843) in a letter to the Bishop of London, in which he made the point that due to the debt incurred by slavery, Africa deserved the spiritual and material benefit of the enterprise (Gibba 2011:55). While the idea did not succeed, it raised the possibility and eventually came to fruition under Principal Richard Rawle. In 1851, the West Indian Church Association was formed and tasked with making the mission to Africa a reality. In 1855, Rev Leacock, a White Englishman, and John Henry A. Duport, an Afro-Kittian and Codrington graduate, left for West Africa. The choice of Rev. Leacock as leader is noteworthy because initial arguments were for Afro-Caribbeans to be sent back to assist in this work. Given the planters' opinion of the former slaves, it is not surprising that a White person was chosen to lead the mission.

Despite his knowledge of the people and area, Duport was constantly placed in subordinate positions, but in September 1863, he was finally promoted due to the inability to find a White clergy replacement (Gibba 2011:147). While he received a salary increase, it was less than his predecessors. In 1868, after his second wife gave birth 5 months after their marriage, he lost his position and salary. Other accusations were lodged against him. He was cleared of all except sexual engagement prior to marriage. Despite this and his numerous pleas, the SPG refused to reinstate his salary (Gibba 2011:160). The intrenched racist behaviour that permeated the SPG for the entirety of Duport's ministry speaks to the contested position of its missionary work in Africa.

\section{Mission in Contemporary Times: Emancipation from Below}

There are many strands within these extraordinary narratives of Barbados' slave/plantation history, the SPG, Christopher Codrington III's vision and bequest, and Codrington College as a contested place/space, with many implications for contemporary missions. Using the framework of 'emancipation from below,' we wish to suggest seven that are relevant for Christian engagement in Barbados and the Caribbean, but which also have resonance for wider missional application.

\subsection{Mission as Contested Place/Space}

First, we argue that it is necessary to acknowledge that in Barbados, mission was a contested place/space. The mission process, while conceptually focused on bringing the gospel to African slaves or emancipated peoples, was a colonization tool wielded to aid Britain's expansion, branding Western Christianity as the authentic expression of Christianity, and embedding a racialized 
conceptualization of 'Whiteness'/British culture as a primary manifestation of God's work in God's people. In this manner, emancipation from above - abolition of slavery, independence, education, black leadership, et cetera - while producing some measure of freedom, did so at great cost to the wellbeing of Caribbean people, stripping African slaves and their descendants of their dignity and humanity. It is also helpful to consider the ways in which global missions may likewise continue to exist in contested places/spaces, as an important element of evaluating missional praxis. As Kortright Davis astutely surmises, "emancipation from above usually benefits the strong and powerful [the status quo], while the poor and weak remain in an unaltered condition. Bondage gives way to new forms of bondage, colonialism makes ways for neocolonialism, patterns of domination change, but never the domination" (Davis 1990:134). Where, then, does one look for the transformation of the structures of domination?

\subsection{Dismantling Structures of Domination}

For contemporary mission and ministry in Barbados and the Caribbean, the gospel of liberation ought to start from below at the sites of erasure/subjugation nurtured within these contested places/spaces: the bodies and personhood of the enslaved/oppressed, enabling "Caribbean people [to] search for a new theological orientation and political vision based on the historical experiences [including slaves personhood, resistance and valuing African heritage] of the Region and the future God calls us to" (Joseph 2018:163). ${ }^{20}$ This emancipation from below requires the empowerment of people hitherto powerless. It includes freeing people's minds from psychological bondage to fully accept themselves - their cultures, dialects, and the "pursuit of human rights at all levels ... and full human development" (Davis 1990:138).

Emancipation from below also grapples with the legacy of the exploitative nature of the closed economic system in the region, where the islands "provided Britain with tropical goods and [were] the necessary outlets for [British] exports" It also analyses the region's historical "unhealthy dependence upon the beneficent and favorable external markets [including foreign investment] for both economic growth and progress" and its contemporary manifestations in IMF debt, exploitative trade agreements, and the dominance of tourism and other sectors requiring foreign investment(McLean-Farrell 2016:49, 50). As such, whether in the Caribbean or more globally, emancipation from below requires a radical transformation of economic systems, fostering innovations

20 In this article, the author gives an analysis of Idris Hamid's view on the emancipation of Caribbean theology, see pp. 161-165. 
in self-employment, stronger management, and more equitable distribution of public and social responsibility within private enterprise (Davis 199o:138).

\subsection{Theological Education}

As we lean into the liberative work of God's Spirit, these missional approaches have two simultaneous movements: internal and external. Within theological spaces like the Church and College, this internal work requires the acknowledgement of complicity with, support for, and maintenance of the status quo both historically and at present - in their structures, leadership, curriculum, and liturgy.

Accompanying this acknowledgement must be a commitment to engaging in the hard work of excavating the embedded forms of institutional oppression. Such work requires the leading of the Spirit, because both people and institutions are marked with this oppression. As previously indicated, critical in this process is the emancipation of the mind, whereby one must critique received knowledge, including the prized legacies of civilization, culture, and westernized expressions of Christianity, and its role in fostering Britain and America's hegemony in the Caribbean basin and around the world. Associated with this critique is the revisiting of, and engagement with, the ideas, cultures, religious beliefs, practices, races, people, perspectives, et cetera, that were deemed 'deviant,' 'pagan,' 'uncivilized,' 'inferior,' or 'worthless' within that framework.

Within this process, the College has a significant role to play in forging direct ties with African theological colleges for the purpose of entering into dialogue with African Christians and the Anglican Church in Africa, with the potential for healing and fruitful theological engagement on all sides. It will also be crucial for more persons to engage in the study of Caribbean Theology driven by a post-colonial/contextual lens, and out of that emerging understanding to allow a new church to emerge. A new theology that draws upon both past and present experiences - including failures and successes, local liturgists, poets, and musicians, and is transplanted from an old colonial mission pot to being firmly rooted with Barbadian soil, will be a rich contribution to global Christianity, representing a truly Caribbean (and not a planters') church.

\subsection{Priesthood of All Believers}

In the coinciding external movement, there are several additional missional approaches to pursue, including the priesthood of all believers. The Anglican Church of Barbados, Codrington College, and the Barbadian society exist within a framework where leadership is often tied to education, and embedded within this leadership framework is the hegemony of rationality as the superior epistemology. However, should we examine the religious autobiography of 
the predominately male priesthood or that of the administrators, staff, and students at Codrington, one finds other ways of knowing - affective, experiential, practical ${ }^{21}$ - embodied in "mothers interested in bringing up their children in the knowledge of God, lay persons exercising leadership roles in their congregations, itinerant preachers yearning to fulfil a prophetic function as they seek to be God's mouthpiece ... indeed [you find] men and women who endeavour to live the Christian faith in their daily activities" (Mulrian 1999:116). Given the significant role mothers play in their families and in Barbadian society, and since women comprise the majority of church membership, re-centering women's roles in the ministry and mission of the Church is crucial. To this end, the Church should assume a prophetic voice and take a lead in "decolonising and feminizing freedom" in Barbados (Noble 2016). The expansion of those deemed 'qualified' to engage in the theological transmission God's of word, as well as valuing different ways of knowing, helps to re-centre the belief in the priesthood of all believers.

\subsection{Crossing Cultural Boundaries}

Crossing cultural boundaries speaks to the need for the development of an 'elastic theology' within the Anglican Church (Acts 15:1-21), stretching to accommodate other forms of Christian spirituality. As we have shown, Codrington College and the Anglican Church have inherited and maintained an exclusivist theology, in which little room was given to other expressions of faith. In fact, there was a willingness to destroy others in the name of the 'right' path. Divestment of the status quo requires gaining an appreciation of the wisdom and cultures of the oppressed and the 'other,' whose lives most visibly reveal the nature of oppression enacted by the status quo. It is also to give space (mental and physical) to their voices and to listen for what God is saying to God's people and to discern the ways in which God extends an invitation to join in God's work in the world.

While some efforts have been made to indigenize the church (using the steel pan in worship, for example), more needs to be done to foster this elastic theology, especially in relation to the adolescents and young adults (ages 10-24), who comprised $19.5 \%$ of the population in 2016 (Ministry of Youth 2020:27). The inability to keep its youth beyond their confirmation (around age 12-13) speaks definitively to the church's need for this elastic theology.

With issues like teenage pregnancy, gender imbalance in educational outcomes, or the over-representation of males in criminal activities, we must

21 For an exploration of the multiple ways of knowing see: John Heron, Feeling and Personhood: Psychology in Another Key (New York: Sage, 1992). 
re-interrogate how the 'accepted norms' around gender roles/identity, female purity/impurity, or masculine virility/promiscuity, and normative family structures, continue to impact our youth while being rooted in the colonial past. The task for church leadership is both to affirm and support this process of elastic theology and to let it change the church. This requires centring the voices, experiences, and realities of the youth - allowing the youth set the agenda for the features of the elastic theologies that speak to the nature of Christ in their contexts. ${ }^{22}$

\subsection{Ecumenism}

Thinking ecumenically, the Caribbean, while predominantly Christian, is a multi-faith space (Johnson and Zurlo 2020:99-100). As such, emancipation from below must also be done within this multi-faith context: "Christians tend to don hats of superiority and therefore, need always to learn how to receive from people of other faiths" (Mulrian 1999:123). Here again, valuing the cultures and religions of the African ancestors have a role to play. As we have shown, the normativity of a European framing of Christianity by the plantocracy and the SPG required the demonization and prohibition of African indigenous religious practices by the slaves. Later, when the emancipated slaves became Christians, they were to embody this same Europeanized Christianity, at the cost of valuing their African ancestry. The internalization of a European mindset and the devaluing of one's culture was not limited to the Afro-Barbadians; it was a central tool used in the European colonization of the world. For the colonized, the devaluing of culture was applied not only to their own but all non-European ones. Within such a framework the Europeans were able to keep colonized people divided and the colonial enterprise secure.

While it is beyond the scope of our focus here, another important aspect requiring significant attention here is the explosive growth of Pentecostalism in Barbados (as in the rest of the world). Aymer notes: "Today Caribbean countries are ablaze with Pentecostal religious fervor. This is evident not only in the long listings of worship services, workshops, prayer meetings, evangelical conferences, and revival campaigns advertised constantly in Caribbean popular media but also in public testimonies and proselytizing on the streets by believers" (Aymer 2016:16). While Christopher Codrington and the SPG envisioned an Anglican theological center for Barbados, as we have seen, this was in many ways a "planters' church," espousing British theologies, liturgies, hymns, and spiritualities that did not fully resonate with the Afro-Barbadian context. As the College and the Anglican Church more widely revisit and further contextualise 
their theology, worship, and praxis, it will be important to reflect upon the ways in which Pentecostalism is resonating among Afro-Barbadians, inspiring new religious imaginations and new ways of doing mission in the Caribbean. While continuing to maintain a clearly Anglican identity, Pentecostals will be important ecumenical partners. ${ }^{23}$

In our contemporary times, as the Anglican Church and Codrington College seek to identify the ancestral genes that have been marked by victimization, marginalization, and anonymity, and instead recover and pass on healed Afro-Barbadian identities, they need to critically access the utilization of division as a tool of control and thus re-discover the appreciation of the culture and wisdom of the 'other': the other within themselves, the other in fellow colonized peoples, the other in different denominations and faith traditions. As they attend to this work, they will encounter their multi-faith 'other', in a way that acknowledges that what kills the other, kills us ${ }^{24}$ and only by working together can they create a society that fosters the wellbeing of all Barbadians.

\subsection{Post-Traumatic Growth}

This story of the SPG, slavery, and Codrington's bequest highlight just one snapshot of the profoundly traumatic experiences of generations of Afro-Barbadians (and indeed all other Africans and African Americans) impacted by slavery and the transatlantic slave trade. While not to trivialise the painful realities of the intergenerational trauma of slavery, research in positive psychology encouragingly indicates that there can be important "post-traumatic growth" (Tedschi and Calhoun 1995:102). We argue that the existence of Codrington College is emblematic of unimaginable trauma: a bequest arising out of the profits of treating Black Africans as subhuman - cargo - real estate; rather than as human beings created in the image of God. However, post-traumatic growth shows that when the horrors of trauma are taken seriously, there can be important, positive outcomes (Thomas, DiGiulio, \& Sheehan 1991:279). As part of the church's mission, Codrington as a theological college might engage with this intergenerational trauma, reflecting theologically upon slavery, the results of uncritical missional hermeneutics, and the consequences for Christian mission when there are close ties with dehumanising economic structures, likewise equipping and empowering clergy to offer appropriate pastoral support.

23 See, for example, Amos Yong and Estrelda Y. Alexander, Afro-Pentecostalism: Black Pentecostal and Charismatic Christianity in History and Culture (New York: New York University Press, 2011).

24 For more on how oppression, specifically racism impacts both the victim and the perpetrator see: Resmaa Menakem, My Grandmother's Hands (Las Vegas: Central Recovery Press, 2017). 
Many Caribbean postcolonial scholars have already embraced posttraumatic growth as a way forward (see Lal 2000). But beyond this, Barbadian Christians and Codrington College also have the theology of resurrection upon which to draw - not as a future promise but a present reality that promises life rather than death, asserting that evil and trauma do not have the last word. In the Barbadian context, engaging the trauma arising from the brutalities of slavery and colonialism through the lens of resurrection theology would make an invaluable contribution to national reconstruction and missions which seek to foster post-traumatic growth, emancipation and empowerment from below. In doing so, Codrington College and the Anglican Church, as institutions in a contested place/space, would not only be reminders of a traumatic past, but symbols of hope and empowerment.

As Codrington College, the Anglican Church of Barbados, and the Barbadian people live into the realities that mark life in the twenty-first century, these theological institutions, and people, do so within an entangled and troubling legacy of colonialism, slavery, and mission. Embedded within this legacy is a tension, as these theological spaces and the Barbadian people have existed and, in many ways, continue to exist, as contested places/spaces, where 'liberation' and oppression go hand in hand. As mission is added to this interrogation, we uncover how missionizing was itself a contested place/space. Charting a new course for mission within twenty-first century Barbados requires divestment from the status quo and an embracing of an emancipation from below, with the acknowledgement that such work is a commitment to the long view, where "God's actions [summons all of God's people] together as a people" in God's work in the world (Williams 2003).

However, these lessons are not limited to Codrington College or Barbados, but as we have argued, have wider implications for the fields of mission studies, theology, biblical studies, and other relevant disciplines. Beyond those already outlined, an acknowledgement is needed to clarify that by virtue of the location (within the hallowed halls of academia) and origin, these disciplines have also been fashioned in a Eurocentric normative framework and perpetuate a Euro-American dominance over knowledge where the 'right to decide' what constitutes truth, valid fields of inquiry, and acceptable knowledge, is determined from seats of power with little to no input from the minds, bodies, and lives these disciplines will shape across the globe. As this article has shown, such epistemological arrogance, paternalism, and erasure/ demonizing of others' wisdom, cultures, and religious experiences - and 
particularly in this case, transatlantic Black/African voices - enslaves and impoverishes us all.

Second, cosmetic changes will not change the system. While some work has been done in these disciplines to bring the voices and realities of 'the other' to the table (contextualization in mission studies, the development of womanist, liberation, and Dalit theologies, etc.), oftentimes there is little acknowledgement that the table itself is a contested space: a place where power and hierarchy reign and other voices are labelled 'exotic.' This table is also a place/ space where the educated, published/written voice is given more credibility and authority than voices that center oral culture and experiences as primary sources of truth and knowledge. As argued above, within these disciplines there is a need for an emancipation from below, where liberation from embedded cultural expressions (within the powerful and the marginalized), aligns with a pursuit of human rights on all levels, just and equitable economic practices, and an embodiment of the truth of the scriptures that moves us towards full human growth and flourishing.

\section{References Cited}

'A Historical Overview of Codrington College.' (n.d.). Available at: http://www.codring ton.org/site/index.php/historical-overview, accessed on June 23, 2021.

Aymer, Paula L. (2016). Evangelical Awakenings in the Anglophone Caribbean Studies from Grenada and Barbados. London: Palgrave.

Beckles, Hilary McD. (2016). The First Black Slave Society: Britain's 'Barbarity Time' in Barbados, 1636-1876. Jamaica; Barbados; Trinidad and Tobago: The University of the West Indies Press. Kindle.

Brock, Colin (1982). "The Legacy of Colonialism in West Indian Education." In Keith Watson, ed., Education in the Third World, London: Croom Helm, pp. 127-28.

Codrington College. Available at: http://www.codrington.org/site/index.php/academic -highlights, accessed on June 2021.

Davis, Kortright (1990). Emancipation Still Comin': Explorations in Caribbean Emancipatory Theology. Maryknoll: Orbis Books.

Fanon, Frantz (1952, 2008). Black Skin, White Masks. New York: Grove Press.

Gibba, Bakary (2011). The West Indian Mission to West Africa: The Rio Pongas Mission, 1850-1963. PhD Thesis, Department of History, University of Toronto.

Glasson, Travis (2012). Mastering Christianity: Missionary Anglicanism and Slavery in the Atlantic World. New York: Oxford University Press.

Hunte, Keith (2001). "Protestantism and Slavery in the British Caribbean." In Armando Lampe, ed., Christianity in the Caribbean: Essays on Church History. Kingston: University of West Indies Press, 686-125. 
Joseph, Celucien L. (2018). "Towards a Caribbean Political Theology of Emancipation and Decolonization: A Comparative Analysis of Four Caribbean Theologians". Black Theology 16 (2): 148-180, DoI: 10.1080/14769948.2018.1460553.

Klingberg, Frank J. (1938). "British Humanitarianism at Codrington". The Journal of Negro History 23 (4): 441-486. DoI: https://doi.org/10.2307/2714582.

Lal, Vinay (2000). "Unanchoring Islands: An Introduction to the Special Issue on 'Islands: Waterways, Flowways, Folkways." Emergences:Journalfor the Study of Media and Composite Cultures 10 (2): 229-240. DoI https://doi.org/10.1080/713665810.

McLean-Farrell, Janice (2014). "Exploring a Scottish Legacy: Lewis Davidson, Knox College and Jamaica's Youth." In Afe Adogame and Andrew Lawrence, eds., Africa in Scotland, Scotland in Africa, Boston: Brill, 150-169.

McLean-Farrell, Janice A. (2016). West Indian Pentecostals: Living their Faith in New York and London. New York: Bloomsbury Press.

Miller, Robert R., Jacinta Ruru, Larissa Behrendt, and Tracey Lindberg (2010). Discovering Indigenous Lands: The Doctrine of Discovery in the English Colonies. New York: Oxford University Press.

Mulrian, George (1999). "Hermeneutics Within a Caribbean Context." In R. S. Sugirtharajah, ed., Vernacular Hermeneutics, Sheffield: Sheffield Academic Press, 116-132.

Noble, Denise (2016). Decolonizing and Feminizing Freedom: A Caribbean Genealogy. London: Palgrave and Macmillan.

O'Connor, Daniel, ed. (2000). Three Centuries of Mission: The United Society for the Propagation of the Gospel 1701-200o. London: Bloomsbury Publishing.

Palmer, Geoff (2007). The Enlightenment Abolished. Penicuik: Henry Publishing.

Simmons, George C. (1972). "West Indian Higher Education - The Story of Codrington College." Caribbean Quarterly 18 (3): 51-72.

Titus, Noel (2010). "Concurrence without Compliance: SPG and the Barbadian Plantations 1710-1834." In Daniel O'Connor and Others, eds., Three Centuries of Mission: The United Society for the Propagation of the Gospel 1701-2000, London: Bloomsbury Publishing, 249-261.

Ward, Kevin (2006). A History of Global Anglicanism. New York: Cambridge University Press.

Williams, Eric (1944, 1994). Capitalism and Slavery. Chapel Hill, NC: University of North Carolina Press.

Williams, The Most Revd Rowan. (2003). Presidential Address to General Synod, By The Most Revd Rowan Williams, Archbishop of Canterbury. Available at: https://www.portsmouth.anglican.org/news/2003/o7/29/presidential-address -to-general-synod-by-the-most-revd-rowan-williams-archbishop-of-canterbury/, accessed on July 2021. 


\section{Resumen}

Parece incongruente nombrar al mismo tiempo la Sociedad para la propagación del evangelio, el seminario y la esclavitud; sin embargo, estos tres están estrechamente vinculados en la historia de Codrington College, Barbados, el primer colegio teológico de la Comunión anglicana. Este trabajo utiliza un enfoque histórico-analítico para poner de manifiesto los preocupantes principios misioneros que extendieron estructuras coloniales opresivas, y fallaron en desarrollar plenamente la personalidad, la organización y la plena emancipación de los oprimidos. Reevaluamos las maneras en que ciertos marcos verticalistas del cristianismo y las misiones, aún bajo el pretexto de emancipación, se utilizaron para esclavizar / oprimir a los afrobarbadenses. Se promueve, en lugar de ello, un modelo centrado en la emancipación desde abajo; se delinea cómo este relato histórico provee una mirada para la hermenéutica / praxis misional contemporánea que busca erradicar las desigualdades raciales y económicas para la liberación de todos.

\section{摘要}

一口气同时提到福音传播的团体、神学院和奴隶制似乎很不协调。然而, 在圣公会 第一所神学院巴巴多斯的科德林顿学院, 我们发现这三者有着千丝万缕的联系。本 文运用历史分析方法, 揭示了令人烦扰的宣教原则, 这些原则推进了压迫性的殖民 结构, 而未能充分培养被压迫者的人格和媒介以致他们得到充分的解放。我们重新 评估了基督教和宣教机构自上而下的框架, 即使打着解放的幌子, 是被用来奴役/ 压迫非洲巴巴迪亚人的方式。相反, 我们主张建立一个以从下解放为中心的框架, 概述了这一历史叙述如何为当代宣教诠释/实践提供见解, 这些诠释/实践寻求根除 种族和经济的不平等, 追求人人解放。 